Article

\title{
Synthesis, Spectral and Antibacterial Studies of Copper(II) Tetraaza Macrocyclic Complexes
}

\section{Puchakayala Muralidhar Reddy ${ }^{1,2}$, Rondla Rohini ${ }^{1,2}$, Edulla Ravi Krishna ${ }^{1}$, Anren Hu ${ }^{3, *}$ and Vadde Ravinder ${ }^{1}, *$}

1 Department of Chemistry, Kakatiya University, Warangal 506 009, A.P, India; E-Mails: pmdreddy@gmail.com (P.M.R.); prmnreddy@gmail.com (R.R.); edulla2008@gmail.com (E.R.K.)

3 Department of Laboratory Medicine and Biotechnology, Tzu Chi University, Hualien 97004, Taiwan

* Authors to whom correspondence should be addressed; E-Mails: anren@ mail.tcu.edu.tw (A.H.); ravichemku@ rediffmail.com (V.R.); Tel.: +886-3-8565301 (ext. 2334 or 2335) (A.H.); +91-9390100594 (V.R.); Fax: +886-3-8571917 (A.H.).

Received: 8 March 2012; in revised form: 11 April 2012 / Accepted: 12 April 2012 /

Published: 19 April 2012

\begin{abstract}
A novel family of tetraaza macrocyclic $\mathrm{Cu}(\mathrm{II})$ complexes $\left[\mathrm{CuLX}_{2}\right]$ (where $\mathrm{L}=\mathrm{N}_{4}$ donor macrocyclic ligands) and $\left(\mathrm{X}=\mathrm{Cl}^{-}, \mathrm{NO}_{3}{ }^{-}\right)$have been synthesized and characterized by elemental analysis, magnetic moments, IR, EPR, mass, electronic spectra and thermal studies. The magnetic moments and electronic spectral studies suggest square planar geometry for $[\mathrm{Cu}(\mathrm{DBACDT})] \mathrm{Cl}_{2}$ and $[\mathrm{Cu}(\mathrm{DBACDT})]\left(\mathrm{NO}_{3}\right)_{2}$ complexes and distorted octahedral geometry to the rest of the ten complexes. The biological activity of all these complexes against gram-positive and gram-negative bacteria was compared with the activity of existing commercial antibacterial compounds like Linezolid and Cefaclor. Six complexes out of twelve were found to be most potent against both gram-positive as well as gram-negative bacteria due to the presence of thio group in the coordinated ligands.
\end{abstract}

Keywords: synthesis; antibacterial studies; tetraaza macrocycles; copper(II) complexes 


\section{Introduction}

Macrocyclic ligands are considerably attractive in the quest for new chemistry, because they offer a wide variety of donor atoms, ionic charges, coordination numbers and geometry of the resultant complexes [1-5]. The understanding of the metal ion chemistry of macrocyclic ligands has important implications for a range of chemical and biochemical applications [6,7]. Many metal complexes of naturally occurring porphyrins, corrins and phthalocyanines have been investigated because of their potential as dyestuffs or pigments [8-11]. Macrocyclic ligand complexes are of great importance in enhancing various industrial applications and in a number of biological processes such as photosynthesis and dioxygen transport [12] catalytic properties, potential applications as metal extractants, radiotherapeutic and medical imaging agents and to potency towards DNA binders [13] with a high potential in anti-tumor therapy, has provided a motivation for investigation of the metal ion chemistry of these systems, as well as of cyclic ligand systems $[8,9,14,15] . \mathrm{Cu}(\mathrm{II})$ is the most studied metal ion among all the transition metal ions $[16,17] . \mathrm{Cu}$ (II) complexes are known to play a significant role either in naturally occurring biological systems or as pharmacological agents $[18,19]$. In connection with previous investigations $[1,2,20]$, on the coordinating properties of tetraaza macrocycles, and in order to isolate new transition metal complexes with potential antimicrobial properties, we have studied the synthesis, spectroscopic and biochemical aspects of tetraaza macrocyclic complexes of copper(II) derived from $o$-phthalaldehyde with various diamines.

\section{Results and Discussion}

A series of twelve tetraaza macrocyclic $\mathrm{Cu}$ (II) complexes were synthesized by treating $\mathrm{CuCl}_{2} \cdot 2 \mathrm{H}_{2} \mathrm{O}$ and $\mathrm{Cu}\left(\mathrm{NO}_{3}\right)_{2} \cdot 3 \mathrm{H}_{2} \mathrm{O}$ with the six macrocyclic Schiff base ligands. All the complexes are stable to the atmosphere. The complexes are soluble in chloroform, DMSO, DMF and aqueous methanol. The elemental analyses (Table 1) are consistent with the proposed structure of the complexes. The molar conductance values of the complexes 1.5 and 2.5 in DMF at room temperature (65.0 and $68.3 \mathrm{ohm}{ }^{-1} \cdot \mathrm{cm}^{2} \cdot \mathrm{mol}^{-1}$ ) confirm their $1: 2$ electrolytic natures and the low molar conductance values of other complexes indicate non-electrolytic nature.

Table 1. Physical, analytical and electronic spectral data of macrocyclic $\mathrm{Cu}(\mathrm{II})$ complexes.

\begin{tabular}{|c|c|c|c|c|c|c|c|c|}
\hline \multirow{2}{*}{$\begin{array}{l}\text { Comp. } \\
\text { No. }\end{array}$} & \multirow{2}{*}{$\begin{array}{l}\text { Cu(II) Compound/ } \\
\text { Molecular Formula }\end{array}$} & \multirow{2}{*}{$\Lambda_{M}$} & \multirow{2}{*}{$\begin{array}{c}\mu \text { eff } \\
\text { (B.M.) }\end{array}$} & \multirow{2}{*}{$\begin{array}{c}\lambda_{\max } \\
\left(\mathbf{c m}^{-1}\right)\end{array}$} & \multicolumn{4}{|c|}{ Analyses (\%) Found (Calculated) } \\
\hline & & & & & $\mathbf{C}$ & $\mathbf{H}$ & $\mathbf{N}$ & $\mathbf{C u}$ \\
\hline 1.1. & $\begin{array}{l}{\left[\mathrm{Cu}(\mathrm{HBOADO}) \mathrm{Cl}_{2}\right]} \\
\mathrm{C}_{18} \mathrm{H}_{16} \mathrm{Cl}_{2} \mathrm{~N}_{8} \mathrm{O}_{2} \mathrm{Cu}\end{array}$ & 16.2 & 1.96 & $\begin{array}{l}16008 \\
21226\end{array}$ & $\begin{array}{c}42.38 \\
(42.32)\end{array}$ & $\begin{array}{l}3.18 \\
(3.16)\end{array}$ & $\begin{array}{l}22.04 \\
(21.94)\end{array}$ & $\begin{array}{c}12.36 \\
(12.44)\end{array}$ \\
\hline 1.2. & $\begin{array}{l}{\left[\mathrm{Cu}(\mathrm{TBACD}) \mathrm{Cl}_{2}\right] \cdot 2 \mathrm{H}_{2} \mathrm{O}} \\
\mathrm{C}_{18} \mathrm{H}_{18} \mathrm{Cl}_{2} \mathrm{~N}_{6} \mathrm{O}_{4} \mathrm{Cu}\end{array}$ & 14.0 & 1.98 & $\begin{array}{l}17348 \\
22801\end{array}$ & $\begin{array}{c}41.33 \\
(41.83)\end{array}$ & $\begin{array}{c}3.52 \\
(3.51)\end{array}$ & $\begin{array}{l}16.23 \\
(16.26)\end{array}$ & $\begin{array}{c}12.25 \\
(12.30)\end{array}$ \\
\hline 1.3. & $\begin{array}{l}{\left[\mathrm{Cu}(\mathrm{OBACI}) \mathrm{Cl}_{2}\right]} \\
\mathrm{C}_{24} \mathrm{H}_{28} \mathrm{Cl}_{2} \mathrm{~N}_{4} \mathrm{Cu}\end{array}$ & 13.5 & 1.96 & $\begin{array}{l}17857 \\
21988\end{array}$ & $\begin{array}{c}56.88 \\
(56.86)\end{array}$ & $\begin{array}{c}5.57 \\
(5.57)\end{array}$ & $\begin{array}{l}11.02 \\
(11.05)\end{array}$ & $\begin{array}{c}12.56 \\
(12.53)\end{array}$ \\
\hline 1.4. & $\begin{array}{l}{\left[\mathrm{Cu}(\mathrm{HBOADT}) \mathrm{Cl}_{2}\right]} \\
\mathrm{C}_{18} \mathrm{H}_{16} \mathrm{Cl}_{2} \mathrm{~N}_{8} \mathrm{~S}_{2} \mathrm{Cu}\end{array}$ & 12.4 & 1.94 & $\begin{array}{l}17847 \\
21255\end{array}$ & $\begin{array}{l}40.01 \\
(39.82)\end{array}$ & $\begin{array}{l}2.84 \\
(2.97)\end{array}$ & $\begin{array}{l}20.72 \\
(20.64)\end{array}$ & $\begin{array}{c}11.55 \\
(11.70)\end{array}$ \\
\hline 1.5 . & $\begin{array}{l}{[\mathrm{Cu}(\mathrm{DBACDT})] \mathrm{Cl}_{2}} \\
\mathrm{C}_{18} \mathrm{H}_{12} \mathrm{Cl}_{2} \mathrm{~N}_{4} \mathrm{~S}_{2} \mathrm{Cu}\end{array}$ & 65.0 & 1.91 & $\begin{array}{l}13065 \\
18181\end{array}$ & $\begin{array}{c}44.42 \\
(44.77)\end{array}$ & $\begin{array}{l}2.68 \\
(2.50)\end{array}$ & $\begin{array}{l}11.72 \\
(11.60)\end{array}$ & $\begin{array}{c}13.07 \\
(13.16)\end{array}$ \\
\hline 1.6. & $\begin{array}{l}{\left[\mathrm{Cu}(\mathrm{TBAHD}) \mathrm{Cl}_{2}\right] \cdot 2 \mathrm{H}_{2} \mathrm{O}} \\
\mathrm{C}_{18} \mathrm{H}_{18} \mathrm{Cl}_{2} \mathrm{~N}_{6} \mathrm{~S}_{2} \mathrm{Cu}\end{array}$ & 16.5 & 1.92 & $\begin{array}{l}17699 \\
22527\end{array}$ & $\begin{array}{c}41.95 \\
(41.82)\end{array}$ & $\begin{array}{r}3.50 \\
(3.51)\end{array}$ & $\begin{array}{c}16.22 \\
(16.26)\end{array}$ & $\begin{array}{c}12.24 \\
(12.29)\end{array}$ \\
\hline
\end{tabular}


Table 1. Cont.

\begin{tabular}{clccccccc}
\hline 2.1. & {$\left[\mathrm{Cu}(\mathrm{HBOADO})\left(\mathrm{NO}_{3}\right)_{2}\right]$} & 15.3 & 1.93 & 16422, & 38.23 & 3.02 & 24.81 & 11.34 \\
& $\mathrm{C}_{18} \mathrm{H}_{16} \mathrm{~N}_{10} \mathrm{O}_{8} \mathrm{Cu}$ & & & 21712 & $(38.34)$ & $(2.86)$ & $(24.84)$ & $(11.27)$ \\
2.2. & {$\left[\mathrm{Cu}(\mathrm{TBACD})\left(\mathrm{NO}_{3}\right)_{2}\right]$} & 16.1 & 1.89 & 17758, & 40.42 & 2.84 & 21.10 & 11.87 \\
& $\mathrm{C}_{18} \mathrm{H}_{14} \mathrm{~N}_{8} \mathrm{O}_{8} \mathrm{Cu}$ & & & 22954 & $(40.49)$ & $(2.64)$ & $(20.99)$ & $(11.90)$ \\
2.3. & {$\left[\mathrm{Cu}(\mathrm{OBACI})\left(\mathrm{NO}_{3}\right)_{2}\right]$} & 14.8 & 1.94 & 18201, & 51.48 & 5.05 & 15.06 & 11.38 \\
& $\mathrm{C}_{24} \mathrm{H}_{28} \mathrm{~N}_{6} \mathrm{O}_{6} \mathrm{Cu}$ & & & 22147 & $(51.47)$ & $(5.04)$ & $(15.01)$ & $(11.35)$ \\
2.4. & {$\left[\mathrm{Cu}(\mathrm{HBOADT})\left(\mathrm{NO}_{3}\right)_{2}\right]$} & \multirow{2}{*}{12.9} & 1.86 & 18348, & 36.24 & 2.68 & 23.42 & 10.72 \\
& $\mathrm{C}_{18} \mathrm{H}_{16} \mathrm{~N}_{10} \mathrm{~S}_{2} \mathrm{O}_{6} \mathrm{Cu}$ & & & 21875 & $(36.27)$ & $(2.71)$ & $(23.50)$ & $(10.66)$ \\
2.5. & {$[\mathrm{Cu}(\mathrm{DBACDT})]\left(\mathrm{NO}_{3}\right)_{2}$} & 68.3 & 1.89 & 13524, & 40.31 & 2.16 & 15.74 & 11.91 \\
& $\mathrm{C}_{18} \mathrm{H}_{12} \mathrm{~N}_{6} \mathrm{~S}_{2} \mathrm{O}_{6} \mathrm{Cu}$ & & & 18457 & $(40.34)$ & $(2.26)$ & $(15.68)$ & $(11.86)$ \\
2.6. & {$\left[\mathrm{Cu}(\mathrm{TBAHD})\left(\mathrm{NO}_{3}\right)_{2}\right]$} & 15.4 & 1.93 & 17700, & 38.12 & 2.54 & 19.82 & 11.34 \\
& $\mathrm{C}_{18} \mathrm{H}_{14} \mathrm{~N}_{8} \mathrm{~S}_{2} \mathrm{O}_{6} \mathrm{Cu}$ & & & 22756 & $(38.20)$ & $(2.49)$ & $(19.80)$ & $(11.23)$ \\
\hline
\end{tabular}

\subsection{Infrared Spectral Data}

The main bands and their assignments are listed in Table 2. In the IR spectra of macrocyclic $\mathrm{Cu}$ (II) complexes, a medium intensity band due to $v_{(\mathrm{C}=\mathrm{N})}$ was shifted towards lower side about $20-33 \mathrm{~cm}^{-1}$ compared to the ligand spectra and was appeared in the range of $1598-1573 \mathrm{~cm}^{-1}$ [21]. The appearance of a lower intensity band in the region of $524-505 \mathrm{~cm}^{-1}$ corresponds to the $v_{(\mathrm{M}-\mathrm{N})}$ vibration supports the fact that the ligands coordinate to the metal ions through the nitrogen of $\mathrm{C}=\mathrm{N}$ group in all the complexes [22-24]. A band present in the range of 318-302 $\mathrm{cm}^{-1}$ in the spectra of 1.1, 1.2, 1.3, 1.4 and 1.6 complexes indicating the presence of two chlorides in trans position around copper center [17,25]. The presence of chloride ions in 1.1, 1.2, 1.3, 1.4 and 1.6 complexes are detected by the addition of silver nitrate reagent leading to the formation of white precipitate. However, in the case of complex 1.5, this band is not observed indicating chloride ions are not in the coordination sphere. The coordination of the nitrate groups have been confirmed in the complexes 2.1, 2.2, 2.3, 2.4 and 2.6 by the band in the region of 230-240 $\mathrm{cm}^{-1}$ may be assigned [9] to $\mathrm{v}_{(\mathrm{M}-\mathrm{O})}$ of the $\mathrm{ONO}_{2}$ group [26]. The additional bands observed around $\sim 1410,1300$ and $1020 \mathrm{~cm}^{-1}$ [25] were obtained in the spectra of the nitrato complexes, which consistent [26] with the monodentate nature of the nitrato group [25,27,28]. The absence of these bands was observed in case of complex 2.5 indicating nitrate groups are not in the coordination sphere. The macrocyclic $\mathrm{Cu}(\mathrm{II})$ compounds (1.2 and 1.6) contain a broad band in the region 3505$3374 \mathrm{~cm}^{-1}$ due to the presence of lattice water molecules[18,22].

Table 2. Infrared spectral data of macrocyclic $\mathrm{Cu}$ (II) complexes.

\begin{tabular}{clcccc}
\hline \multirow{2}{*}{$\begin{array}{c}\text { Comp. } \\
\text { No. }\end{array}$} & \multicolumn{1}{c}{$\mathbf{C u}(\mathbf{I I})$ Compound } & \multicolumn{4}{c}{ Selected IR Bands $\left(\mathbf{c m}^{-\mathbf{1}}\right)$} \\
\cline { 3 - 6 } & & $\mathbf{v}_{\mathbf{C}=\mathbf{N}}$ & $\mathbf{v}_{\mathbf{N H}}$ & $\mathbf{v}_{\mathbf{C u}-\mathbf{N}}$ & Anion Peaks \\
\hline 1.1. & {$\left[\mathrm{Cu}(\mathrm{HBOADO}) \mathrm{Cl}_{2}\right]$} & 1578 & 3320 & 516 & 307 \\
1.2. & {$\left[\mathrm{Cu}(\mathrm{TBACD}) \mathrm{Cl}_{2}\right]_{2} \cdot \mathrm{H}_{2} \mathrm{O}$} & 1575 & 3326 & 518 & 304 \\
1.3. & {$\left[\mathrm{Cu}(\mathrm{OBACI}) \mathrm{Cl}_{2}\right]$} & 1596 & - & 520 & 318 \\
1.4. & {$\left[\mathrm{Cu}(\mathrm{HBOADT}) \mathrm{Cl}_{2}\right]$} & 1590 & 3324 & 524 & 302 \\
1.5. & {$[\mathrm{Cu}(\mathrm{DBACDT})] \mathrm{Cl}_{2}$} & 1598 & - & 506 & - \\
1.6. & {$\left[\mathrm{Cu}(\mathrm{TBAHD}) \mathrm{Cl}_{2}\right]_{2} \cdot \mathrm{H}_{2} \mathrm{O}$} & 1585 & 3383 & 520 & 314 \\
\hline
\end{tabular}


Table 2. Cont.

\begin{tabular}{cccccc}
\hline \multirow{2}{*}{$\begin{array}{c}\text { Comp. } \\
\text { No. }\end{array}$} & \multirow{2}{*}{$\mathbf{C u}(\mathrm{II})$ Compound } & \multicolumn{4}{c}{ Selected IR bands $\left(\mathbf{c m}^{-\mathbf{1}}\right)$} \\
\cline { 3 - 6 } & & $\mathbf{v}_{\mathbf{C}=\mathbf{N}}$ & $\boldsymbol{v}_{\mathbf{N H}}$ & $\boldsymbol{v}_{\mathbf{C u}-\mathbf{N}}$ & Anion Peaks \\
\hline 2.1. & {$\left[\mathrm{Cu}(\mathrm{HBOADO})\left(\mathrm{NO}_{3}\right)_{2}\right]$} & 1580 & 3318 & 510 & 235 \\
2.2. & {$\left[\mathrm{Cu}(\mathrm{TBACD})\left(\mathrm{NO}_{3}\right)_{2}\right]$} & 1573 & 3325 & 515 & 230 \\
2.3. & {$\left[\mathrm{Cu}(\mathrm{OBACI})\left(\mathrm{NO}_{3}\right)_{2}\right]$} & 1595 & - & 518 & 240 \\
2.4. & {$\left[\mathrm{Cu}(\mathrm{HBOADT})\left(\mathrm{NO}_{3}\right)_{2}\right]$} & 1587 & 3326 & 520 & 230 \\
2.5. & {$[\mathrm{Cu}(\mathrm{DBACDT})]\left(\mathrm{NO}_{3}\right)_{2}$} & 1595 & - & 505 & - \\
2.6. & {$\left[\mathrm{Cu}(\mathrm{TBAHD})\left(\mathrm{NO}_{3}\right)_{2}\right]$} & 1580 & 3379 & 518 & 235 \\
\hline
\end{tabular}

\subsection{EPR Spectral Data}

The EPR spectra of the $\mathrm{Cu}(\mathrm{II})$ complexes have been recorded at room temperature as well as at liquid nitrogen temperature and their $\mathrm{g}_{11}$ and $\mathrm{g} \perp$ values have been calculated. The observed data show that $\mathrm{g}_{11}=2.085-2.219$ and $\mathrm{g}_{\perp}=2.018-2.046$ (Table 3). The values of $\mathrm{g}_{11}$ and $\mathrm{g}_{\perp}$ are closer to 2 and $\mathrm{g}_{11}>\mathrm{g} \perp$. This suggests that the unpaired electron is in the $\mathrm{d}_{\mathrm{x} 2-\mathrm{y} 2}$ orbital and hence, ${ }^{2} \mathrm{~B}_{1}$ is the ground state. It should be noted that for an ionic environment $\mathrm{g}_{11}>2.3$, while for a covalent environment $\mathrm{g}_{11}<2.3$. The copper complexes show $\mathrm{g}_{11}<2.3$ indicating their considerable covalent character $[9,29]$. The $g$ values are related by the expression $G=\left(g_{11}-2\right) /(g \perp-2)$ which suggests an exchange interaction between copper centers in the polycrystalline solid. According to Hathway [30] if $G>4$, the exchange interaction is negligible. In the present case, the axial symmetry parameter, $G$, lies in the range 4.025-5.896, which indicates no considerable exchange interaction in these solid complexes.

Table 3. EPR spectral data of macrocyclic $\mathrm{Cu}(\mathrm{II})$ compounds.

\begin{tabular}{clcccc}
\hline Comp. No. & \multicolumn{1}{c}{$\mathbf{C u}(\mathbf{I I})$ Compound } & $\mathbf{g}_{\mathbf{1 1}}$ & $\mathbf{g}_{\perp}$ & $|\mathbf{g}|_{\text {avg }}$ & $\mathbf{G}$ \\
\hline 1.1. & {$\left[\mathrm{Cu}(\mathrm{HBOADO}) \mathrm{Cl}_{2}\right]$} & 2.119 & 2.024 & 2.055 & 4.958 \\
1.2. & {$\left[\mathrm{Cu}(\mathrm{TBACD}) \mathrm{Cl}_{2}\right] \cdot 2 \mathrm{H}_{2} \mathrm{O}$} & 2.212 & 2.043 & 2.099 & 4.930 \\
1.3. & {$\left[\mathrm{Cu}(\mathrm{OBACI}) \mathrm{Cl}_{2}\right]$} & 2.118 & 2.021 & 2.053 & 5.619 \\
1.4. & {$\left[\mathrm{Cu}(\mathrm{HBOADT}) \mathrm{Cl}_{2}\right]$} & 2.219 & 2.039 & 2.099 & 5.615 \\
1.5. & {$[\mathrm{Cu}(\mathrm{DBACDT})] \mathrm{Cl}_{2}$} & 2.220 & 2.046 & 2.104 & 4.782 \\
1.6. & {$\left[\mathrm{Cu}(\mathrm{TBAHD}) \mathrm{Cl}_{2}\right] \cdot 2 \mathrm{H}_{2} \mathrm{O}$} & 2.171 & 2.029 & 2.076 & 5.896 \\
2.1. & {$\left[\mathrm{Cu}(\mathrm{HBOADO})\left(\mathrm{NO}_{3}\right)_{2}\right]$} & 2.108 & 2.022 & 2.050 & 4.909 \\
2.2. & {$\left[\mathrm{Cu}(\mathrm{TBACD})\left(\mathrm{NO}_{3}\right)_{2}\right]$} & 2.177 & 2.040 & 2.085 & 4.425 \\
2.3. & {$\left[\mathrm{Cu}(\mathrm{OBACI})\left(\mathrm{NO}_{3}\right)_{2}\right]$} & 2.085 & 2.018 & 2.040 & 4.722 \\
2.4. & {$\left[\mathrm{Cu}(\mathrm{HBOADT})\left(\mathrm{NO}_{3}\right)_{2}\right]$} & 2.165 & 2.030 & 2.075 & 5.500 \\
2.5. & {$[\mathrm{Cu}(\mathrm{DBACDT})]\left(\mathrm{NO}_{3}\right)_{2}$} & 2.161 & 2.040 & 2.080 & 4.025 \\
2.6. & {$\left[\mathrm{Cu}(\mathrm{TBAHD})\left(\mathrm{NO}_{3}\right)_{2}\right]$} & 2.110 & 2.019 & 2.049 & 5.789 \\
\hline
\end{tabular}

\subsection{Electronic Spectra and Magnetic Data}

The magnetic moment of all the $\mathrm{Cu}$ (II) complexes at room temperature lie in the range of $1.86-1.98$ B.M. given in Table 1, corresponding to one unpaired electron. This indicates that these complexes are monomeric in nature and the absence of metal-metal interaction [17]. The electronic spectra of the complexes $\left[\mathrm{Cu}(\mathrm{L}) \mathrm{X}_{2}\right]\left(\mathrm{X}=\mathrm{Cl}^{-}, \mathrm{NO}_{3}{ }^{-}\right)$display two characteristic bands in the region 21226-22801 $\mathrm{cm}^{-1}$ and $16008-18348 \mathrm{~cm}^{-1}$ these may be assigned to ${ }^{2} \mathrm{~B}_{1 \mathrm{~g}} \rightarrow{ }^{2} \mathrm{E}_{\mathrm{g}}$ and ${ }^{2} \mathrm{~B}_{1 \mathrm{~g}} \rightarrow{ }^{2} \mathrm{~A}_{1 \mathrm{~g}}$ transitions respectively. 
The third band assigned to ${ }^{2} \mathrm{~B}_{1 \mathrm{~g}} \rightarrow{ }^{2} \mathrm{~B}_{2 \mathrm{~g}}$ transition band is usually not observed as a separate band in the tetragonal field. Therefore, it may be concluded that all the $\left[\mathrm{Cu}(\mathrm{L}) \mathrm{X}_{2}\right]$ complexes show distorted octahedral structure (Scheme) [31]. The complexes $[\mathrm{Cu}(\mathrm{L})] \mathrm{X}_{2}$ display broad band in the region 18181-18457 $\mathrm{cm}^{-1}$ and $13065-13524 \mathrm{~cm}^{-1}$ corresponding to transitions ${ }^{2} \mathrm{~B}_{1 \mathrm{~g}} \rightarrow{ }^{2} \mathrm{E}_{\mathrm{g}}$ and ${ }^{2} \mathrm{~B}_{1 \mathrm{~g}} \rightarrow{ }^{2} \mathrm{~A}_{1 \mathrm{~g}}$ which suggests the square planar geometry [19].

\subsection{Thermal Analysis}

Thermograms of TGA and DTA of macrocyclic $\mathrm{Cu}(\mathrm{II})$ compounds were recorded in nitrogen atmosphere at a heating rate of $10{ }^{\circ} \mathrm{C} / \mathrm{min}$. In the thermogram of complexes $\left[\mathrm{Cu}(\mathrm{TBACD}) \mathrm{Cl}_{2}\right] \cdot 2 \mathrm{H}_{2} \mathrm{O}$ (1.2) and $\left[\mathrm{Cu}(\mathrm{TBAHD}) \mathrm{Cl}_{2}\right] \cdot 2 \mathrm{H}_{2} \mathrm{O}(\mathbf{1 . 5})$, the initial weight loss of $15.36 \%$ (Calcd $\left.15.28 \%\right)$ and $14.45 \%$ (Calcd $14.37 \%$ ) at $70-110{ }^{\circ} \mathrm{C}$ corresponding to loss of two lattice held water molecules [18,22]. This fact was further supported by their DTA curves, which contain endothermic peaks in the temperature range $90-125^{\circ} \mathrm{C}$. The TGA decomposition curve, a peak corresponding to the loss of organic moiety in the temperature range of $238-252{ }^{\circ} \mathrm{C}$ was observed. On the other hand, the thermograms of other macrocyclic $\mathrm{Cu}$ (II) compounds showed only a single decomposition curve in the region $220-260{ }^{\circ} \mathrm{C}$ corresponding to the loss of organic moiety. Above $455{ }^{\circ} \mathrm{C}$, organic moieties in macrocyclic $\mathrm{Cu}$ (II) compounds were decomposed leading to the formation of copper oxide.

\subsection{Mass Spectral Analysis}

In the mass spectra of respective macrocyclic $\mathrm{Cu}(\mathrm{II})$ complexes, molecular ion peaks, were observed at different $\mathrm{m} / \mathrm{z}\left(\mathrm{M}^{+} /[\mathrm{M}+\mathrm{Na}]^{+}\right)$values. The molecular ion peaks and isotopic pattern of $\mathrm{Cu}$ (II) complexes shows different $\mathrm{m} / \mathrm{z}$ values with different intensities. The mass spectra contain molecular ion peaks at $m / z 511\left(\mathrm{M}^{+}\right.$, complex 1.1), $517\left(\mathrm{M}^{+}\right.$, complex 1.2), $507\left(\mathrm{M}^{+}\right.$, complex 1.3), $543\left(\mathrm{M}^{+}\right.$, complex 1.4), $483\left(\mathrm{M}^{+}\right.$, complex 1.5), $517\left(\mathrm{M}^{+}\right.$, complex 1.6), $563\left(\mathrm{M}^{+}\right.$, complex 2.1), 586 $\left([\mathrm{M}+\mathrm{Na}]^{+}\right.$, complex 2.1), $533\left(\mathrm{M}^{+}\right.$, complex 2.2), $560\left(\mathrm{M}^{+}\right.$, complex 2.3), $583\left([\mathrm{M}+\mathrm{Na}]^{+}\right.$, complex 2.3), $595\left(\mathrm{M}^{+}\right.$, complex 2.4), $535\left(\mathrm{M}^{+}\right.$, complex 2.5), and $565\left(\mathrm{M}^{+}\right.$, complex 2.6). This data is in good agreement with the respective molecular formulae.

Based on the physicochemical and the spectral studies the tentative structures proposed for the complexes are shown in Scheme 1.

Scheme 1. Representative structures of copper complex.
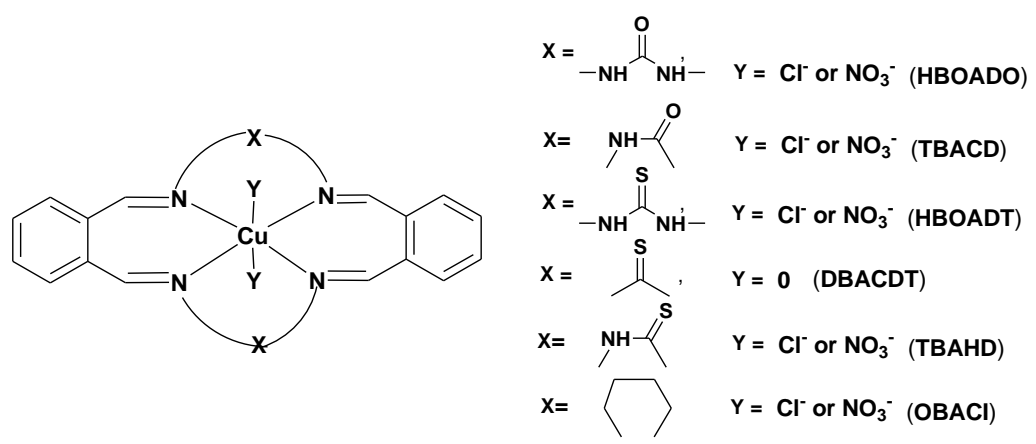


\subsection{Biological Results and Discussion}

Twelve chemically synthesized $\mathrm{Cu}(\mathrm{II})$ macrocyclic complexes were tested in vitro for their antibacterial activity against five test bacteria namely $S$. aeruginosa, S. epidermidis, B. pumilus, $B$. megaterium and $P$. aeruginosa. The minimum inhibitory concentrations of complexes were determined by liquid dilution method. The minimum inhibitory concentration at which no growth was observed was taken as the MIC values. All the complexes of the tested series possessed good antibacterial activity against both gram-positive bacteria and gram-negative bacteria. The higher antibacterial activity of the copper complexes is may be due to the change in structure due to coordination and chelating tends to make metal complexes act as more powerful and potent bactereostatic agents, thus inhibiting the growth of the bacteria. Six complexes out of twelve (1.4, 1.5, 1.6, 2.4, $2.5 \&$ 2.6) were most potent against both gram-positive as well as gram-negative bacteria. However, complexes 1.1, 1.2, 1.3, 2.1, $2.2 \& 2.3$ were also showed noticeable MIC ranging from 1-16 $\mu \mathrm{g} / \mathrm{mL}$ against $S$. aeruginosa, B. pumilus and B. megaterium (Table 5). The gram positive were much more susceptible to the series as compared to gram-negative bacteria. The twelve $\mathrm{Cu}$ (II) complexes were also compared with two commercial antibiotics namely Linezoid and Cefaclor. The six complexes 1.4, 1.5, 1.6, 2.4, $2.5 \& \mathbf{2 . 6}$ registered better antibacterial in comparison with commercial antibiotics. The activity of these complexes is due to the presence of thio group in the coordinated ligands. Comparison of MIC values (in $\mu \mathrm{g} / \mathrm{mL}$ ) of $\mathrm{Cu}$ (II) macrocyclic complexes and standard drugs against different bacteria are given in Figure 1.

Table 5. Minimum inhibitory concentration (MIC) of $\mathrm{Cu}$ (II) macrocyclic complexes against test bacteria.

\begin{tabular}{clccccc}
\hline \multirow{2}{*}{$\begin{array}{c}\text { Comp. } \\
\text { No. }\end{array}$} & \multirow{2}{*}{ Macrocyclic Cu(II) Complexes } & \multicolumn{5}{c}{ MIC $(\boldsymbol{\mu g} / \mathbf{m L})$} \\
\cline { 3 - 7 } & & $\mathbf{S a}$ & $\mathbf{B p}$ & $\mathbf{B m}$ & $\mathbf{P a}$ & $\mathbf{S e}$ \\
\hline 1.1. & {$\left[\mathrm{Cu}(\mathrm{HBOADO}) \mathrm{Cl}_{2}\right]$} & 8 & 6 & 10 & 16 & 12 \\
1.2. & {$\left[\mathrm{Cu}(\mathrm{TBACD}) \mathrm{Cl}_{2}\right] \cdot 2 \mathrm{H}_{2} \mathrm{O}$} & 8 & 10 & 16 & 8 & 12 \\
1.3. & {$\left[\mathrm{Cu}(\mathrm{OBACI}) \mathrm{Cl}_{2}\right]$} & 16 & 10 & 8 & 12 & 9 \\
1.4. & {$\left[\mathrm{Cu}(\mathrm{HBOADT}) \mathrm{Cl}_{2}\right]$} & 2 & 4 & 4 & 16 & 2 \\
1.5. & {$[\mathrm{Cu}(\mathrm{DBACDT})] \mathrm{Cl}_{2}$} & 2 & 8 & 4 & $<16$ & 1 \\
1.6. & {$\left[\mathrm{Cu}(\mathrm{TBAHD}) \mathrm{Cl}_{2}\right] \cdot 2 \mathrm{H}_{2} \mathrm{O}$} & 4 & 4 & 2 & 16 & 2 \\
2.1. & {$\left[\mathrm{Cu}(\mathrm{HBOADO})\left(\mathrm{NO}_{3}\right)_{2}\right]$} & 10 & $<16$ & 8 & $>16$ & 10 \\
2.2. & {$\left[\mathrm{Cu}(\mathrm{TBACD})\left(\mathrm{NO}_{3}\right)_{2}\right]$} & 10 & 10 & 8 & 16 & 12 \\
2.3. & {$\left[\mathrm{Cu}(\mathrm{OBACI})\left(\mathrm{NO}_{3}\right)_{2}\right]$} & 16 & 8 & 16 & $>16$ & $>16$ \\
2.4. & {$\left[\mathrm{Cu}(\mathrm{HBOADT})\left(\mathrm{NO}_{3}\right)_{2}\right]$} & 2 & 2 & 4 & 16 & 1 \\
2.5. & {$[\mathrm{Cu}(\mathrm{DBACDT})]\left(\mathrm{NO}_{3}\right)_{2}$} & 2 & 4 & 4 & $<16$ & 2 \\
2.6. & {$\left[\mathrm{Cu}(\mathrm{TBAHD})\left(\mathrm{NO}_{3}\right)_{2}\right]$} & 4 & 2 & 4 & 16 & 2 \\
& Linezolid & 4 & 4 & 4 & $<16$ & $<16$ \\
& $\mathrm{Cefaclor}$ & 2 & 8 & 8 & $<16$ & 2 \\
\hline
\end{tabular}

Sa: S. aeruginosa (ATCC-29213); Bp: B. pumilus (MTCC-1456); Bm: B. megaterium (MTCC-428); Pa: P. aeruginosa (ATCC-27853); Se: S. epidermidis (MTCC-2639). 
Figure 1. Comparison of MIC values (in $\mu \mathrm{g} / \mathrm{mL}$ ) of $\mathrm{Cu}(\mathrm{II})$ macrocyclic complexes and standard drugs against different bacteria.

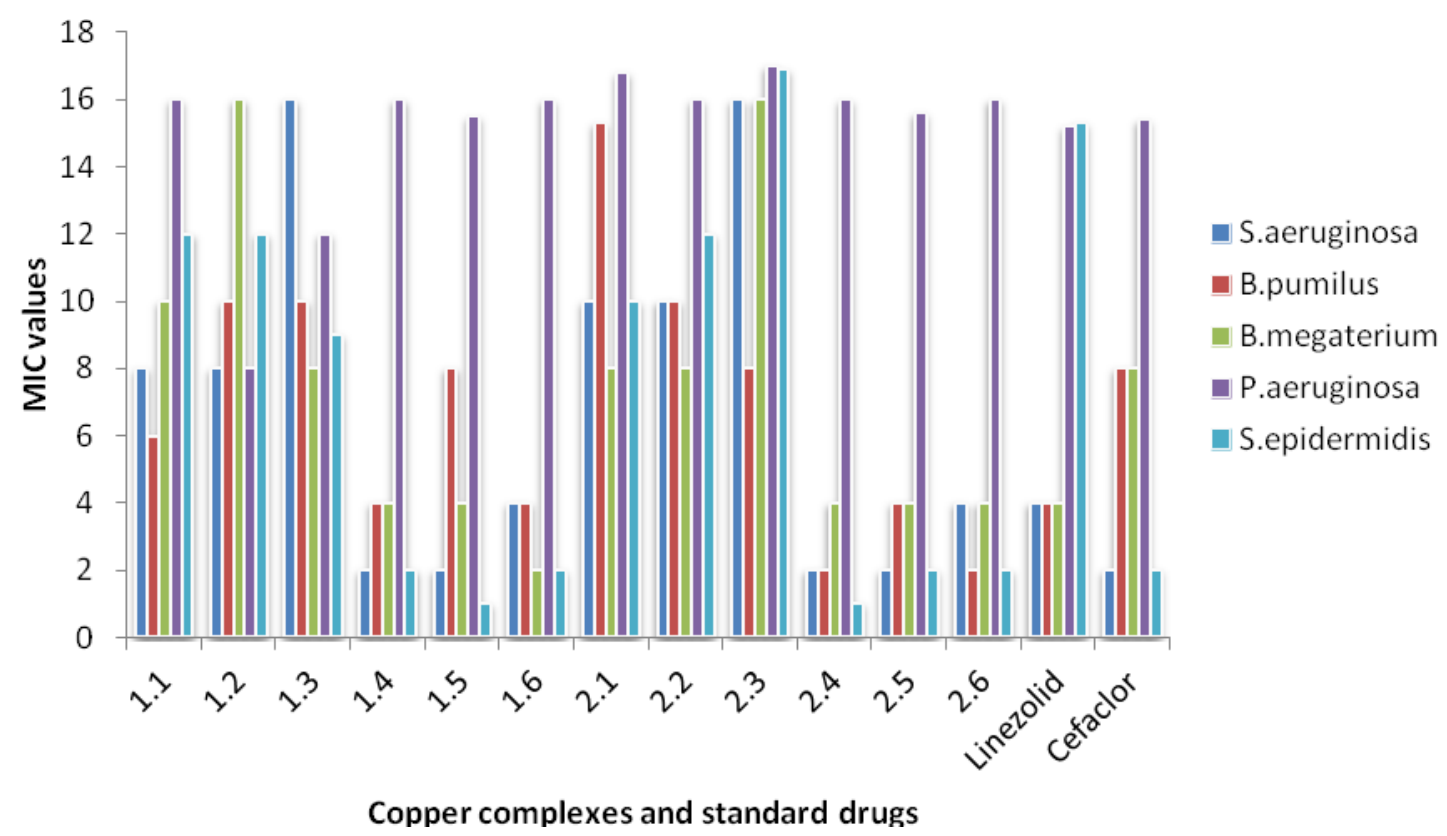

\section{Experimental Section}

\subsection{Materials and Methods}

The metal salts $\mathrm{CuCl}_{2} \cdot 2 \mathrm{H}_{2} \mathrm{O}$ and $\mathrm{Cu}\left(\mathrm{NO}_{3}\right)_{2} \cdot 3 \mathrm{H}_{2} \mathrm{O}$ were purchased from E. Merck. All the chemicals used were of AR grade and were procured from Aldrich. All solvents used were of AR grade. Six macrocyclic ligands viz. 7,8,9,18,19,20-hexahydrodibenzo[ $g, p] \quad[1,2,4,5,10,11,13,14]$ octaazacyclooctadecine-8,19-dione [HBOADO], 7,8,17,18-tetrahydrodibenzo[f,n] [1,2,4,9,11,12]hexaazacyclohexadecine-8,17-dione [TBACD], 7,8,9,10,19,20,21,22-octahydrodibenzo[ $c, m]$ $[1,6,11,16]$-tetraazacycloicosine $\quad$ [OBACI $], \quad 7,8,9,18,19,20$-hexahydrodibenzo[ $[g, p]$ $[1,2,4,5,10,11,13,14]$-octaazacyclooctadecine-8,19-dithione $\quad$ [HBOADT], 7,16-dihydrodibenzo[e,l] $[1,3,8,10]$-tetraazacyclo tetradecine-7,16-dithione [DBACDT] and 7,8,17,18-tetrahydrodibenzo[f,n] [1,2,4,9,11,12]-hexaazacyclohexadecine-8,17-dithione [TBAHD] were synthesized according to the procedure reported by shanker et al. [32]. Gram positive microorganisms like Staphylococcus aeruginosa (ATCC-29213), Staphylococcus epidermidis (MTCC-2639), Bacillus pumilus (MTCC-1456), Bacillus megaterium (MTCC-428) and gram negative microorganism like Pseudomonas aeruginosa (ATCC-27853) from IMTECH, Chandigarh were used for antibacterial studies.

\subsection{Measurements}

The elemental analyses were obtained by using a Perkin-Elmer-2400 CHN elemental analyzer. The complexes were analyzed for $\mathrm{Cu}$ (II) content gravimetrically by literature procedures (Vogel AI (1989) Vogel's text book of quantitative chemical analysis, 5th edition Longman, Amsterdam) after decomposing the organic matter with a mixture of $\mathrm{HNO}_{3}$ and $\mathrm{HCl}$ and evaporating the residue to dryness with concentrated $\mathrm{H}_{2} \mathrm{SO}_{4}$. UV-Vis spectra were recorded on Shimadzu UV-160A 
spectrophotometer, EPR spectra were recorded on Varian E-112X-Q band EPR Spectrometer. IR spectra in $\mathrm{KBr}$ pellets on Perkin-Elmer-283 spectrophotometer. LC-ESI MS was used to obtain mass spectra. Gouy balance calibrated with $\mathrm{Hg}\left[\mathrm{Co}(\mathrm{NCS})_{4}\right]$ was used for the determination of magnetic susceptibilities of complexes in solid state at room temperature. Thermograms were recorded on mettler-TA-2000C model. TG-DSC equilibrated at $25 \pm 0.05{ }^{\circ} \mathrm{C}$. The electrical conductivities of $10^{-3} \mathrm{M}$ solutions in dichloromethane were performed using Digisun Digital conductivity meter model DL-909.

\subsection{Synthesis of Dichloro/Nitrato Cu(II) Complexes [CuLX $\left.X_{2}\right]$}

To a stirred solution of the respective copper salts $(0.519 \mathrm{~g}, 0.003 \mathrm{~mol})$ dissolved in methanol $(\sim 20 \mathrm{~mL})$ in a round-bottomed flask, methanolic solution $(\sim 25 \mathrm{~mL})$ of ligand $(0.003 \mathrm{~mol}$., viz. $1.17 \mathrm{~g}$ of HBOADO, $1.038 \mathrm{~g}$ of TBACD, $1.116 \mathrm{~g}$ of OBACI, $1.26 \mathrm{~g}$ of HBOADT, $1.044 \mathrm{~g}$ of DBACDT, $1.134 \mathrm{~g}$ of TBAHD respectively) were added with the help of a dropping funnel. The reaction mixture was stirred magnetically. The resulting solution was concentrated to $5 \mathrm{~mL}$ under reduced pressure and a few $\mathrm{mL}$ of diethyl ether was added to initiate the crystallization. The resulting precipitate was separated by suction filtration, washed several times with diethyl ether, dried in vacuo and was recrystallized using dichloromethane and diethyl ether solvent mixture.

\section{Conclusions}

In the present communication, we have synthesized and characterized twelve copper (II) complexes containing tetraaza macrocyclic ligands. Based on the analytical and spectral data, we assume that the complexes $(1.5 \& \mathbf{2 . 5})$ are square planar and the rest of the complexes show distorted octahedral geometry. All the complexes of the tested series were found to have good antibacterial activity. Complexes 1.4, 1.5, 1.6, 2.4, $2.5 \& 2.6$ were most potent against both gram-positive as well as gram-negative bacteria due to the presence of thio group in the coordinated ligands.

\section{Acknowledgments}

The authors thank the University Grant Commission (UGC, F. No. 34-363/2008(SR)), New Delhi, India for financially supporting this research. We also thank the National Science Council and Tzu Chi University of Taiwan for supporting this research financially.

\section{References}

1. Reddy, P.M.; Prasad, A.V.S.S.; Rohini, R.; Ravinder, V. Catalytic reduction of pralidoxime in pharmaceuticals by macrocyclic $\mathrm{Ni}(\mathrm{II})$ compounds derived from orthophthalaldehyde. Spectrochim. Acta A 2008, 70, 704-712.

2. Reddy, P.M.; Prasad, A.V.S.S.; Shanker, K.; Ravinder, V. Synthesis, spectral studies and antibacterial activity of novel macrocyclic Co(II) compounds. Spectrochim. Acta A 2007, $68,1000-1006$. 
3. Lim, I.-T.; Choi, K.-Y. One-dimensional hydrogen-bonded infinite chain from nickel(II) tetraaza macrocyclic complex and 1,2-cyclopentanedicarboxylate ligand. Int. J. Mol. Sci. 2011, 12, 2232-2241.

4. Reddy, P.M.; Ho, Y.-P.; Shanker, K.; Rohini, R.; Ravinder, V. Physicochemical and biological characterization of novel macrocycles derived from $o$-phthalaldehyde. Eur. J. Med. Chem. 2009, 44, 2621-2625.

5. Borisova, N.E.; Reshetova, M.D.; Ustynyuk, Y.A. Metal-free methods in the synthesis of macrocyclic Schiff bases. Chem. Rev. 2006, 107, 46-79.

6. Ma, W.; Tian, Y.-P.; Zhang, S.-Y.; Wu, J.-Y.; Fun, H.-K.; Chantrapromma, S. Synthesis and characterization of 1,8-bis(ferrocenylmethyl)-5,5,12,12,14-hexamethyl-1,4,8,11tetraazacyclotetradecane, a macrocyclic ligand and its complexes. Transition Met. Chem. 2006, 31, 97-102.

7. Martin, E.M.; Bereman, R.D.; Singh, P. X-ray crystallographic studies of nickel(II) complexes of tetradentate [N2S2]2-ligands. 3. A stepwise distortion from square-planar to pseudotetrahedral geometries. Inorg. Chem. 1991, 30, 957-962.

8. Verma, S.; Chandra, S.; Dev, U.; Joshi, N. Synthesis, spectral and biological studies of nitrogen-sulphur donor macrocyclic ligands and their transition metals complexes. Spectrochim. Acta A 2009, 74, 370-374.

9. Khan, T.A.; Tabassum, S.; Azim, Y.; Shakir, M. Synthesis and physico-chemical studies on 18-membered octaazamacrocyclic complexes of $\mathrm{Mn}(\mathrm{II}), \mathrm{Co}(\mathrm{II}), \mathrm{Ni}(\mathrm{II}), \mathrm{Cu}(\mathrm{II})$, and $\mathrm{Zn}(\mathrm{II})$ ions. Synth. React. Inorg. Met. Org. Chem. 2004, 34, 1305-1318.

10. Gupta, S.K.; Kushwah, Y.S. Mononuclear iron(III)macrocyclic complexes derived from 4-methyl-2,6-di(formyl/benzoyl)phenol and diamines: Synthesis, spectral speciation and electrochemical behaviour. Polyhedron 2001, 20, 2019-2025.

11. Qian, M.; Gou, S.-H.; Ju, H.-X.; Huang, W.; Duan, C.-Y.; You, X.-Z. A mononuclear manganese(III) complex of an asymmetric macrocyclic ligand with a ring contraction $\left[\mathrm{MnHL} 2\left(\mathrm{ClO}_{4}\right)\right]\left(\mathrm{ClO}_{4}\right) \cdot 2.5 \mathrm{H}_{2} \mathrm{O}$. Transit. Met. Chem. 2000, 25, 584-588.

12. Chandra, S.; Gupta, K. Chromium(III), manganese(II), iron(III), cobalt(II), nickel(II) and copper(II) complexes with a pentadentate, 15-membered new macrocyclic ligand. Transit. Met. Chem. 2002, 27, 196-199.

13. Liu, J.; Lu, T.-B.; Deng, H.; Ji, L.-N.; Qu, L.-H.; Zhou, H. Synthesis, DNA-binding and cleavage studies of macrocyclic copper(II) complexes. Transit. Met. Chem. 2003, 28, 116-121.

14. Jubert, C.; Mohamadou, A.; Guillon, E.; Barbier, J.-P. Molecular structure and spectroscopic characterization of cobalt and copper complexes with a hexadentate nitrogen ligand, 1,10-bis(2-pyridylmethyl)-1,4,7,10-tetraazadecane. Polyhedron 2000, 19, 1447-1453.

15. Grguric, S.R.; Sabo, T.J. Synthesis and characterization of sym-cis- and unsym-cis-(ethylenediamine- $N, N^{1}$-Di-3-Propionato)cobalt(III) complexes with symmetrical $N, N^{1}$-substituted diamines. Synth. React. Inorg. Met. Org. Chem. 1999, 29, 1567-1578.

16. Ajibade, P.A.; Zulu, N.H. Metal complexes of diisopropylthiourea: Synthesis, characterization and antibacterial studies. Int. J. Mol. Sci. 2011, 12, 7186-7198.

17. Reddy, P.M.; Prasad, A.V.S.S.; Ravinder, V. Synthesis, spectral characterization, catalytic and antibacterial activity of macrocyclic CuII compounds. Transit. Met. Chem.2007, 32, 507-513. 
18. Budige, G.; Puchakayala, M.R.; Kongara, S.R.; Hu, A.; Vadde, R. Synthesis, characterization and biological evaluation of mononuclear $\mathrm{Co}(\mathrm{II}), \mathrm{Ni}(\mathrm{II}), \mathrm{Cu}(\mathrm{II})$ and $\mathrm{Pd}(\mathrm{II})$ complexes with new $\mathrm{N}_{2} \mathrm{O}_{2}$ Schiff base ligands. Chem. Pharm. Bull. 2011, 59, 166-171.

19. Chandra, S.; Jain, D.; Sharma, A.K.; Sharma, P. Coordination modes of a Schiff base pentadentate derivative of 4-aminoantipyrine with cobalt(II), nickel(II) and copper(II) metal ions: Synthesis, spectroscopic and antimicrobial studies. Molecules 2009, 14, 174-190.

20. Reddy, P.M.; Prasad, A.V.S.S.; Reddy, C.K.; Ravinder, V. Synthesis of new macrocyclic rhodium(III) compounds and their utility as catalysts for the oxidation of ascorbic acid. Transit. Met. Chem. 2008, 33, 251-258.

21. Shanker, K.; Rohini, R.; Ravinder, V.; Reddy, P.M.; Ho, Y.-P. Ru(II) complexes of $\mathrm{N}_{4}$ and $\mathrm{N}_{2} \mathrm{O}_{2}$ macrocyclic Schiff base ligands: Their antibacterial and antifungal studies. Spectrochim. Acta A 2009, 73, 205-211.

22. Geeta, B.; Shravankumar, K.; Reddy, P.M.; Ravikrishna, E.; Sarangapani, M.; Reddy, K.K.; Ravinder, V. Binuclear cobalt(II), nickel(II), copper(II) and palladium(II) complexes of a new Schiff-base as ligand: Synthesis, structural characterization, and antibacterial activity. Spectrochim. Acta A 2010, 77, 911-915.

23. Shakir, M.; Varkey, S.P.; Kumar, D. Binuclear transition metal complexes of Schiff base macrocycles containing the furanyl moiety. Synth. React. Inorg. Met. Org. Chem. 1994, 24, 941-952.

24. Chandra, S.; Gupta, N.; Gupta, R., Novel copper(II) homobinuclear macrocyclic complexes: Cyclic voltammetry, biological properties and spectral studies. Spectrochim. Acta A 2006, 63, 587-593.

25. Reddy, M.B.; Shanker, K.; Rani, P.U.; Rohini, R.; Reddy, C.K.; Ravinder, V. New cobalt(II) tetraaza macrocyclic complexes: Synthesis, spectral and antimicrobial studies. Int. J. ChemTech. Res. 2007, 84, 971-977.

26. Shakir, M.; Chishti, H.; Azim, Y.; Begum, N. Synthesis and characterization of hexaazamacrocyclic complexes with $\mathrm{Co}(\mathrm{II}), \mathrm{Ni}(\mathrm{II}), \mathrm{Cu}(\mathrm{II})$, and $\mathrm{Zn}$ (II) derived from phthalaldehyde and 2,6-diaminopyridine. Synth. React. Inorg. Met. Org. Chem. 2004, 34, 809-818.

27. Chandra, S.; Sangeetika, X. EPR, magnetic and spectral studies of copper(II) and nickel(II) complexes of Schiff base macrocyclic ligand derived from thiosemicarbazide and glyoxal. Spectrochim. Acta A 2004, 60, 147-153.

28. Shakir, M.; Chishti, H.-T.-N.; Chingsubam, P. Metal ion-directed synthesis of 16-membered tetraazamacrocyclic complexes and their physico-chemical studies. Spectrochim. Acta A 2006, 64, 512-517.

29. Bazzicalupi, C.; Bencini, A.; Berni, E.; Bianchi, A.; Borsari, L.; Giorgi, C.; Valtancoli, B.; Lodeiro, C.; Lima, J.C.; Parola, A.J.; et al. Protonation and coordination properties towards Zn(II), $\mathrm{Cd}(\mathrm{II})$ and $\mathrm{Hg}$ (II) of a phenanthroline-containing macrocycle with an ethylamino pendant arm. Dalton Trans. 2004, 591-597.

30. Hathaway, B.J.; Tomlinson, A.A.G. Copper(II) ammonia complexes. Coord. Chem. Rev. 1970, $5,1-43$. 
31. Singh, D.; Kumar, R.; Tyagi, P. Template synthesis, spectroscopic studies and biological screening of macrocyclic complexes derived from thiocarbohydrazide and benzil. Transit. Met. Chem. 2006, 31, 970-973.

32. Shanker, K.; Reddy, P.M.; Rohini, R.; Ravinder, V. Synthesis and spectral studies of novel biologically active macrocycles derived from $O$-phthalaldehyde. Pharm. Lett. 2009, 1, 97-107.

(C) 2012 by the authors; licensee MDPI, Basel, Switzerland. This article is an open access article distributed under the terms and conditions of the Creative Commons Attribution license (http://creativecommons.org/licenses/by/3.0/). 